\title{
SHEAR WAVE ELASTOGRAPHY OF SALIVARY AND THYROID GLANDS IN PEDIATRIC PATIENTS WITH FMF AND AMYLOIDOSIS
}

\author{
FMF VE AMILOIDOZ TANISI ALAN PEDIATRIK HASTALARDA TÜKÜRÜK VE TIROID \\ BEZLERINDE SHEAR WAVE ELASTOGRAFI DEĞERLENDIRME
}

\author{
Zuhal BAYRAMOĞLU ${ }^{1}$ (D) Oya KÖKER ${ }^{2}$ (D) Sedat Giray KANDEMiRLi ${ }^{3}$ (D) ibrahim ADALETLi ${ }^{4}$ (D), \\ Rukiye EKER ÖMEROĞLU² (iD) \\ Istanbul University, Istanbul Faculty of Medicine, 'Department of Radiology, ${ }^{2}$ Department of Pediatric Rheumatology, Istanbul, Turkey \\ ${ }^{3}$ University of lowa Hospital and Clinics, Department of Radiology, lowa, United States of America \\ ${ }^{4}$ Istanbul University-Cerrahpasa, Cerrahpasa Faculty of Medicine, Department of Radiology, Istanbul, Turkey
}

ORCID IDs of the authors: Z.B. 0000-0002-2080-2647; O.K. 0000-0002-0101-9585; S.G.K. 0000-0002-3976-4062; i.A. 0000-0003-4531-6466; R.E.Ö. 0000-0002-3740-6552

Cite this article as: Bayramoglu Z, Koker O, Kandemirli SG, Adaletli I, Eker Omeroglu R. Shear wave elastography of salivary and thyroid glands in pediatric patients with FMF and amyloidosi. J Ist Faculty Med 2020;83(2):92-9. doi: 10.26650/IUITFD.2019.0090

\section{ABSTRACT}

Objective: The aim of this study is to investigate the effects of recurrent inflammation and amyloid deposition on salivary and thyroid gland elasticity in pediatric patients with Familial Mediterranean Fever (FMF) using shear wave ultrasound elastography.

Material and Method: This study included 31 patients with a diagnosis of FMF. At the time of imaging, 22 patients were admitted to the rheumatology department with an acute attack (45\% girls, mean age \pm SD: $13.3 \pm 4.6$ years). The remaining nine patients had histopathologically proven amyloidosis ( $50 \%$ girls, mean age \pm SD: $17.4 \pm 7.1$ years). The control group comprised 40 healthy children (50\% girls; mean age: $11.6 \pm 4.6$ years). Shear wave elastography (SWE) measurements of the bilateral parotid, submandibular and thyroid glands were performed.

Results: The median shear wave elasticity and velocity values of the salivary and thyroid glands in FMF patients imaged during an acute attack and patients with amyloidosis were significantly higher compared to the normal control subjects. However, the elastography values between FMF patients imaged during acute attack and patients with amyloidosis were not significantly different. The cut-off values for differentiation of patients with FMF from control subjects were $9.1 \mathrm{kPa}, 9 \mathrm{kPa}$ and $9.9 \mathrm{kPa}$ for parotid, submandibular and thyroid glands, respectively. There were moderate negative correlations between thyroid $(r=-0.6$, $\mathrm{p}=0.008)$ and parotid gland $(r=-0.4 ; \mathrm{p}=0.04)$ elasticity with $\mathrm{C}$-re-

\section{ÖZET}

Amaç: Bu çalışmanın amacı, Ailevi Akdeniz Ateşi (FMF) tanısı olan çocuk hastalarda tekrarlayan inflamasyon ve amiloid birikiminin tükrük ve tiroid bezi doku sertliği üzerindeki etkilerini araştırmaktır.

Gereç ve Yöntem: Bu çalışma FMF tanısı almış 31 hastayı içermekteydi. Görüntüleme sırasında, 22 FMF hastası akut atak ile romatoloji kliniğine yatırıldı (\%45 kız, yaş ort. \pm SS: $13,3 \pm 4,6$ yıl). Kalan 9 hasta histopatolojik olarak amiloidoz tanısı almıştı (\%50

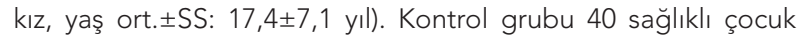

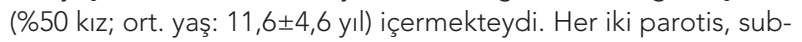
mandibular ve tiroid bezlerine shear wave elastografi ile değerlendirme yapıldı.

Bulgular: Akut atak sırasında görüntülenen FMF hastalarında ve amiloidoz hastalarında tükürük ve tiroid bezlerinin ortanca shear wave elastikiyet ve hız değerleri normal kontrol grubuna göre anlamlı derecede yüksek bulundu. Elastografi değerleri akut atak ve amiloidoz grubu arasında istatistiksel olarak anlamlı farklılık oluşturmamaktaydı. Kontrol grubu ile FMF'li hastalar arasındaki eşik değerleri parotis, submandibular ve tiroid bezleri için sırasıyla 9,1 kPa, $9 \mathrm{kPa}$ ve 9,9 kPa idi. Tiroid ( $r=-0,6$, $p=0,008)$ ve parotis bezi $(r=-0,4 ; p=0,04)$ esneklik değerleri ile C-reaktif protein arasında, ve serum amiloid $A$ ile tiroid bezi esnekliği $(r=-0,58, p=0,018)$ arasında orta dereceli negatif korelasyon mevcuttu.

Corresponding author/iletişim kurulacak yazar: incezuhal@yahoo.com

Submitted/Başvuru: 31.10.2019• Revision Requested/Revizyon Talebi: 28.11.2019 •

Last Revision Received/Son Revizyon: 28.11.2019 • Accepted/Kabul: 16.12.2019 • Published Online/Online Yayın: 27.02.2020

(C)Telif Hakkı $2020 \mathrm{~J}$ Ist Faculty Med - Makale metnine jmed.istanbul.edu.tr web sayfasından ulaşılabilir.

CCopyright 2020 by J Ist Faculty Med - Available online at jmed.istanbul.edu.tr 
active protein and between serum amyloid $A$ with thyroid gland elasticity ( $r=-0.58, p=0.018)$.

Conclusion: Both acute inflammation and amyloid deposition would contribute to increased tissue stiffness. SWE might reflect clinically occult changes in salivary and thyroid glands that could not be demonstrated by routine gray scale ultrasonography in patients with FMF.

Keywords: Children, shear wave elastography, amyloidosis
Sonuç: Hem akut enflamasyon hem de amiloid birikimi, doku sertliğinin artmasına katkıda bulunabilir. SWE FMF'li hastalarda tükürük ve tiroid bezlerinde rutin gri skala ultrasonografi ile gösterilemeyen ve kliniğe henüz yansımamış değişiklikleri ortaya çıkarabilir.

Anahtar Kelimeler: Çocuk, shear wave elastografi, amiloidoz

\section{INTRODUCTION}

Familial Mediterranean Fever (FMF) is an autosomal recessivly inherited autoinflammatory disease characterized by recurrent episodes of fever, polyserositis, and long-term renal complications due to amyloid deposition. There is a predilection for certain regions, mainly affecting the Mediterranean region including Turks (with an incidence of 1/40 0-1/1000), Armenians, Jews, and Arabs (1). The MEFV gene responsible for FMF, encodes protein called pyrin. Pyrin protein regulates inflammatory pathways through interleukin-1 production and mutations results in unregulated excessive inflammatory response with febrile attacks. The main aim of treatment is to prevent acute attacks, suppress subclinical inflammation between the attacks and prevent the development of amyloidosis (2). The amyloid deposition can affect different regions including the thyroid gland (3), lymph nodes, liver (4), abdominal fat tissue, minor salivary glands, spleen and kidney resulting in end-stage renal disease. Early diagnosis of FMF and detection of amyloidosis are crucial for initiation of treatment and patient management.

Monitorization and follow-up of patients with FMF are based on levels of serum C-reactive protein (CRP), erythrocyte sedimentation rate (ESR), white blood cell (WBC), serum amyloid $A(S A A)$ and urine protein. SAA levels reflect subclinical inflammation with high sensitivity but suffer from lower specificity in predicting the development of amyloidosis (5). Ultrasound can be used for its ease of use and superficial location of salivary glands. Resolution of the images among imaging techniques would be highest by using ultrasonography with a linear probe. Parenchymal heterogeneity, enlargement of the gland and changes in the vascularity as well as the fibrotic bands and mass lesions could be clearly represented with ultrasonography. The ultrasound features of Sjögren's syndrome in major the salivary gland have been described as hypoechoic lesions with hyperechoic septations in enlarged salivary glands (6). However, the ultrasonographically detectable appearance may be because of chronic parotitis due to Sjögren's syndrome. However, findings in cases of involvement with amyloidosis would be occult on gray scale ultrasonography. There have been limited findings about the appearance of amyloidosis on ultrasonography. A recent study revealed that heterogeneity and hypoechoic area score have been found to be higher in light chain amyloidosis compared to control subjects (6). Further assessment of tissue amyloidosis can be performed with histopathological analysis using Congo red staining. However, this requires invasive methods. A noninvasive evaluation for amyloid deposition could be performed using elastography which reflects the stiffness of the tissues (79). These studies depicted elasticity changes in hepatic elasticity in patients with amyloidosis using ultrasound elastography. Elastography has been investigated for differentiation between salivary gland tumors (10), and assessment of parenchymal changes in Sjogren's disease (11), and chronic recurrent parotitis (12). However, no previous study has been carried out investigating salivary glands or thyroid gland elasticity in cases of amyloidosis or FMF.

The aim of this study was to investigate the median stiffness values of thyroid and salivary glands in patients with FMF and histopathologically proven amyloidosis secondary to FMF. Another purpose was to investigate possible laboratory associations with tissue stiffness.

\section{MATERIAL AND METHOD}

This was a prospective study performed in control subjects and patients with FMF between January 2018 and September 2019. Istanbul Medical Faculty local ethics committee approval was obtained (File number: 2017/1182). Informed consents were obtained from the legal guardians of participants.

\section{Patients}

The patient population included 31 pediatric patients with a diagnosis of FMF based on positive mutation analysis results, laboratory data of increased inflammatory markers, pertinent clinical history and response to treatment with colchicine. Of the 31 patients, 9 patients had a histopathological diagnosis of renal amyloidosis secondary to FMF. Forty healthy pediatric volunteers were included as the control group. Gray scale ultrasonography and shear wave elastography were performed in 22 patients within the week of the acute FMF attack period, which included active clinical symptoms in additi- 
on to increased CRP, ESR, and SAA levels. Nine patients with histopathologically proven amyloidosis secondary to FMF were imaged during their clinical or radiological follow-up as an outpatient.

\section{Clinical and laboratory findings}

The genetic analysis results for FMF patients were reviewed and recorded. Body mass index (weight $(\mathrm{kg})$ / (height(meter) $)^{2}$, number of acute attacks within the last year, the duration of medication, and the age at initial diagnosis were reviewed and recorded for the FMF group with acute attack. SAA, CRP, ESR levels obtained during imaging and thyroid stimulating hormone (TSH), and free thyroxine (fT4) levels obtained within three months of imaging were also reviewed and recorded.

\section{Shear Wave Elastography (SWE) Evaluation}

Gray scale ultrasound and elastography assessments were performed by a single radiologist with more than seven years of pediatric ultrasound and two years of SWE experience. Images were acquired with ultrasound device using a 14-MHz linear array transducer (Aplio 500 Platinium, Canon, Japan) equipped with elastography application. Three different measurements were obtained for SWE using region of interest that was $5 \mathrm{~mm}$ in diameter for bilateral parotid, submandibular, and thyroid glands. Median stiffness values were recorded both as shear wave elasticity (SWe, $\mathrm{kPa}$ ) and shear wave velocity (SWv, $\mathrm{m} / \mathrm{sec}$ ) values

Thyroid and salivary gland ultrasound evaluations were performed on the patient in a supine position with neck in slight hyperextension. Patients were instructed to minimize swallowing and stay still during imaging. Patients who cooperated fully during imaging allowing optimal propagation maps were included. In thyroid gland SWE, the transducer was positioned parallel to the longitudinal axis of the thyroid lobes. The gland parenchyma was assessed for echogenicity and heterogeneity. Radiological evidence of autoimmune thyroid disease was accepted as exclusion criteria. For submandibular gland evaluation, the transducer was placed parallel to the basis of the mandibular body. During parotid gland evaluation, the transducer was positioned in the preauricular region parallel to the mandibular ramus. Hypoechoic areas and echogenic bands in the salivary glands considering parenchmal infiltration with any other disease or a mass lesion were a cause of exclusion. All examinations were performed using real time optimal propagation maps (Figure 1-3)

\section{Statistical analysis}

Statistical analysis was performed using SPSS (version 21.0, SPSS Inc.). Descriptive analysis of quantitative variables including age, weight, height, Body Mass Index $(\mathrm{BMI})$, shear wave elasticity $(\mathrm{kPa})$, and shear wave velocity $(\mathrm{m} / \mathrm{sec})$, were expressed as mean \pm standard deviati-

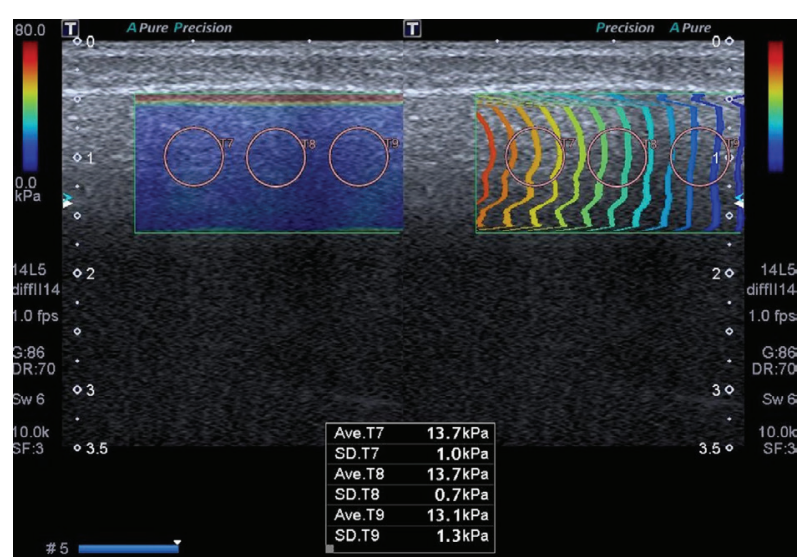

Figure 1: Shear wave elastography image of the right parotid gland in a 15 year-old male patient diagnosed with amyloidosis showed the median elasticity as $13.7 \mathrm{kPa}$.

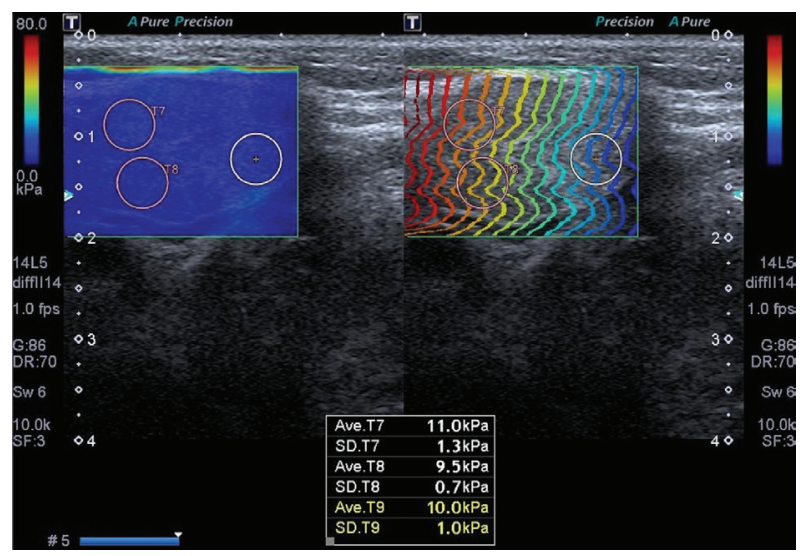

Figure 2: Shear wave elastography image of the right submandibular gland of a 16 year-old patient diagnosed with amyloidosis showed the median elasticity as $10 \mathrm{kPa}$.

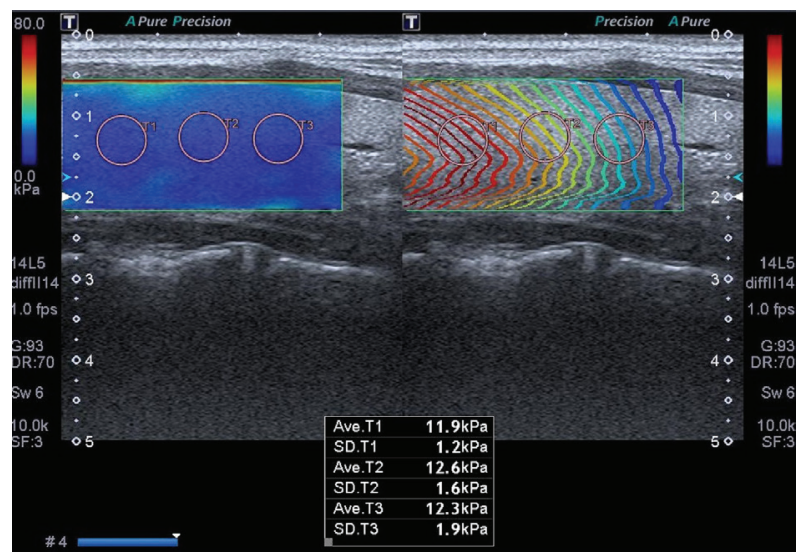

Figure 3: Shear wave elastography image of the right thyroid lobe of a 16 year-old male patient diagnosed with amyloidosis showed the median elasticity as $12.6 \mathrm{kPa}$. 
on or median with interquartile range. Kruskal Wallis and ANOVA tests were used to compare three independent groups. Spearman's correlation analysis was performed to evaluate the relationship between elasticity parameters with the clinical and laboratory parameters. A p value of $<0.05$ was considered as statistically significant.

\section{RESULTS}

Twenty two FMF patients were imaged during acute attack (45\% girls; mean age \pm SD: $13.3 \pm 4.6$ years). Additionally, 9 FMF patients with histopathologically proven amyloidosis were evaluated (50\% girls; mean age \pm SD: $17.4 \pm 7.1$ years). The control group comprised 40 healthy children (50\% girls; mean age: $11.6 \pm 4.6$ years). Descriptive statistics regarding age, weight, height and $\mathrm{BMI}$ values of the participants in the study subgroups and control group are given in Table 1. There was no significant difference between mean values of weight, height and BMI of the participants between the study and control groups. The mean age of the participants in the amyloidosis group was higher than FMF patients with acute admission (13.28 \pm 4.59 vs $17.4 \pm 7.1 ; p=0.001)$.

According to the genotype distribution; 12 patients were homozygous, heterozygous or compound heterozygous for four main MEFV mutations (p.M680I, p.M694V, p.M694I, and p.V726A) on exon 10 gene region. M694V homozygosity was recorded in 5 patients. Two patients had compound heterozygosity for pyrin variant $\mathrm{M} 680 \mathrm{I}(\mathrm{G} / \mathrm{C}) / \mathrm{M} 694 \mathrm{I}$ whereas two were compound heterozygous for M680I (G/C)/ V726A and M694V/N726A, respectively. Four patients were found to harbor exon 10 mutations as heterozygous with M694V $(n=2)$, M680I (G/C) $(n=1)$, V726A ( $n=1)$ mutations. Therefore, only 4 of the 23 patients were treated with colchicine alone and the remaining were resistant to colchicines treatment. The mean duration of the disease was 5.69 years, the mean duration of the colchicines treatment was 4.47 years, and the mean attack number per year was 1.9 in patients with acute admission.

The median shear-wave elasticity values and comparison between groups are given in Table 2 (Figure 4). Shear

Table 1: Descriptive statistics and comparison of three groups with LSD test

\begin{tabular}{|c|c|c|c|c|}
\hline Parameter & $\begin{array}{l}\text { Group } 1 \\
\text { (Control) }\end{array}$ & $\begin{array}{c}\text { Group } 2 \\
\text { (FMF attack) }\end{array}$ & $\begin{array}{c}\text { Group } 3 \\
\text { (Amyloidosis) }\end{array}$ & LSD \\
\hline Age (year) & $11.6 \pm 4.59$ & $13.28 \pm 4.59$ & $17.4 \pm 7.1$ & $\begin{array}{c}1 \text { vs } 2: 0.19 \\
2 \text { vs } 3: 0.3 \\
1 \text { vs } 3: 0.001\end{array}$ \\
\hline Height (cm) & $146.5 \pm 24.9$ & $148.09 \pm 22.12$ & $156 \pm 18.5$ & $\begin{array}{l}1 \text { vs } 2: 0.79 \\
2 \text { vs } 3: 0.39 \\
1 \text { vs } 3: 0.17\end{array}$ \\
\hline Weight (kg) & $47.6 \pm 23.5$ & $45.09 \pm 16.45$ & $50.21 \pm 18.24$ & $\begin{array}{l}1 \text { vs } 2: 0.79 \\
2 \text { vs } 3: 0.39 \\
1 \text { vs } 3: 0.17\end{array}$ \\
\hline BMI $\left(\mathrm{kg} / \mathrm{m}^{2}\right)$ & $20.34 \pm 5.25$ & $19.98 \pm 4.07$ & $19.77 \pm 3.54$ & $\begin{array}{l}1 \text { vs } 2: 0.76 \\
2 \text { vs } 3: 0.9 \\
1 \text { vs } 3: 0.69\end{array}$ \\
\hline
\end{tabular}

Table 2: Descriptive statistics and comparison of the shear wave elasticity (kPa) values of three groups with Mann Whitney U test

\begin{tabular}{lllllll}
\hline & $\begin{array}{l}\text { Right parotid } \\
\text { gland } \\
\text { SWe (IOR) } \\
(\mathrm{kPa})\end{array}$ & $\begin{array}{l}\text { Left parotid } \\
\text { gland } \\
\text { SWe (IQR) } \\
(\mathrm{kPa})\end{array}$ & $\begin{array}{l}\text { Right subman- } \\
\text { dibular gland } \\
\text { SWe (IQR) } \\
(\mathrm{kPa})\end{array}$ & $\begin{array}{l}\text { Left subman- } \\
\text { dibular gland } \\
\text { SWe (IQR) } \\
(\mathrm{kPa})\end{array}$ & $\begin{array}{l}\text { Right thyroid } \\
\text { gland SWe } \\
(\mathrm{IQR}) \\
(\mathrm{kPa})\end{array}$ & $\begin{array}{l}\text { Left thyroid } \\
\text { gland } \\
\text { SWe (IOR) } \\
(\mathrm{kPa})\end{array}$ \\
\hline FMF & $9.7(8.3-12.6)$ & $10.0(8.6-13)$ & $8.9(8.1-9.8)$ & $9.5(8.3-9.9)$ & $10.8(9.2-12.2)$ & $11.0(8.6-12.9)$ \\
Amyloidosis & $12.2(9.5-15.4)$ & $10.2(10.2-15.5)$ & $10.8(10-11.5)$ & $10.2(9.6-11.2)$ & $11.9(9.8-13.2)$ & $11(9.7-12.1)$ \\
Control & $7.96(6.6-9.4)$ & $8.00(7.1-9.5)$ & $8.6(7.8-9.3)$ & $8.6(7.7-9.4)$ & $9.4(8.4-10)$ & $10.0(8.4-10.5)$ \\
$\mathrm{p}^{1}$ & 0.001 & $<0.001$ & 0.37 & 0.022 & 0.021 & 0.058 \\
$\mathrm{p}^{2}$ & 0.001 & 0.001 & 0.004 & 0.022 & 0.036 & 0.053 \\
$\mathrm{p}^{3}$ & 0.12 & 0.68 & 0.057 & 0.46 & 0.40 & 0.91 \\
\hline
\end{tabular}

${ }^{1}$ Control vs FMF, ${ }^{2}$ Control vs Amyloidosis, ${ }^{3}$ FMF vs Amyloidosis, IQR: Interquartile range, SWe: shear wave elasticity 
wave elastography values of parotid, submandibular and thyroid glands were significantly higher in patients with FMF and amyloidosis compared to control subjects. The median elastography values of thyroid and salivary glands were higher in the amyloidosis group compared to the FMF patients with acute attack, however this difference failed to reach statistical significance.

The median shear wave velocity values of the parotid, submandibular and thyroid glands in the control subjects were $1.63 \mathrm{~m} / \mathrm{sec}, 1.7 \mathrm{~m} / \mathrm{sec}, 1.77 \mathrm{~m} / \mathrm{sec}$ on the right and $1.65 \mathrm{~m} / \mathrm{sec}, 1.7 \mathrm{~m} / \mathrm{sec}, 1.83 \mathrm{~m} / \mathrm{sec}$ on the left, respectively. The median shear wave velocity values for the parotid, submandibular and thyroid glands were $1.82 \mathrm{~m} / \mathrm{sec}$, $1.73 \mathrm{~m} / \mathrm{sec}, 1.9 \mathrm{~m} / \mathrm{sec}$ on the right and $1.83 \mathrm{~m} / \mathrm{sec}, 1.79$ $\mathrm{m} / \mathrm{sec}, 1.91 \mathrm{~m} / \mathrm{sec}$ on the left in the FMF patients imaged during acute attack and $2.02 \mathrm{~m} / \mathrm{sec}, 1.9 \mathrm{~m} / \mathrm{sec}, 1.99 \mathrm{~m} /$ $\mathrm{sec}$ on the right and $1.85 \mathrm{~m} / \mathrm{sec}, 1.85 \mathrm{~m} / \mathrm{sec}, 1.92 \mathrm{~m} / \mathrm{sec}$ on the left in the patients with amyloidosis, respectively. SWe and SWv values present linear correlation based on the Young Modulus, and the median SWe values are gi-

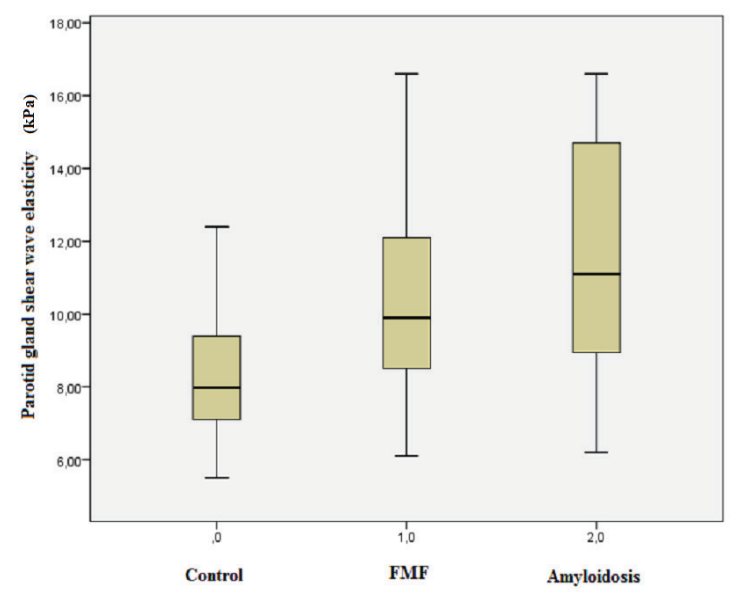

Figure 4: Box plot graphic for median SWe values of bilateral parotid glands (n: 142) among groups. ven in Table 2. The SWe values of the parotid, submandibular and thyroid glands were significantly higher in patients with FMF with or without amyloidosis compared to the control subjects.

Shear wave elastography values of salivary glands and thyroid glands were also positively correlated with each other (Table 3). There was statistically significant moderate positive correlation between duration of colchicine medication and submandibular gland stiffness $(r=0.48$,

Table 3: Spearman correlation analysis

\begin{tabular}{lcclcc}
\hline & R & P & r & P \\
\hline R SM - R P & 0.3 & 0.003 & R P - R T & 0.4 & 0.001 \\
R SM - L P & 0.24 & 0.019 & R P - L SM & 0.46 & 0.001 \\
R SM - R T & 0.29 & 0.005 & L P - R T & 0.36 & 0.001 \\
R SM - L SM & 0.43 & 0.001 & L P - L SM & 0.45 & 0.001 \\
RP - LP & 0.88 & 0.001 & R T - L SM & 0.29 & 0.005 \\
\hline
\end{tabular}

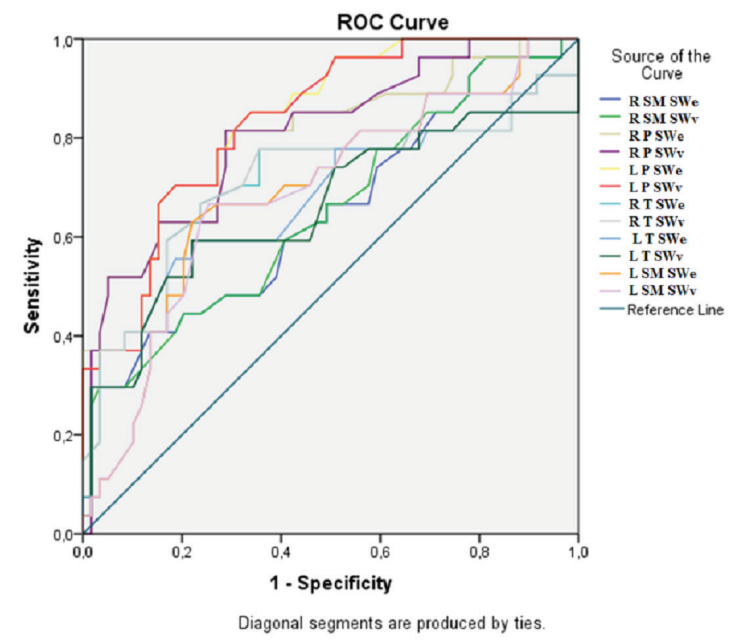

Figure 5: ROC curves plotted for salivary and thyroid gland shear wave elastography values.

Table 4: ROC curve analysis

\begin{tabular}{lcccc}
\hline & Area under the curve (\%) & Cut-off (kPa) & Sensitivity (\%) & Specificity (\%) \\
\hline R SM SWe & 65 & 9 & 51 & 61 \\
R SM SWv & 65 & 1.73 & 60 & 40 \\
R P SWe & 80 & 8.42 & 81 & 70 \\
R P SWv & 80 & 9.2 & 72 & 70 \\
L P SWe & 83 & 9.1 & 70 & 73 \\
L P SWv & 83 & 1.7 & 77 & 70 \\
R S SWe & 71 & 9.9 & 70 & 68 \\
R S SWv & 71 & 1.82 & 70 & 68 \\
L T SWe & 66 & 10.1 & 59 & 61 \\
L T SWv & 65 & 1.9 & 51 & 78 \\
L SM SWe & 69 & 9 & 70 & 60 \\
LSM SWv & 69 & 1.74 & 66 & 63 \\
\hline
\end{tabular}


$p=0.02)$. No significant difference was found between thyroid gland SWe with and without thyroid dysfunction. There was a statistically significant negative correlation of SAA with left thyroid gland SWe $(r=-0.58, p=0.018)$ and SWv. There was a statistically significant moderate negative correlation of CRP with parotid gland SWe $(r=-0.4$; $p=0.04)$, and thyroid gland SWe $(r=-0.6, p=0.008)$.

Receiver-operating characteristic (ROC) curves were plotted for the SWe values of the parotid, submandibular and thyroid glands based on the differentiation of FMF from control subjects (Table 4, Figure 5). For the parotid, submandibular and thyroid glands, a cut-off value of $9.1 \mathrm{kPa}$, $9 \mathrm{kPa}$ and $9.9 \mathrm{kPa}$ achieved the highest area under the curve respectively.

\section{DISCUSSION}

FMF is a multisystemic autoinflammatory disease characterized by recurrent episodes of fever, polyserositis, and long-term renal complications. The main aim of treatment is to decrease the amount of attacks and delay the amyloid deposition, which can affect a variety of organs. Amyloidosis has been reported in $12.9 \%$ of patients with FMF in a large multicenter study from Turkey (13). Different diagnostic methods can be used for the detection of amyloid deposition secondary to autoinflammatory disease. However, these are invasive procedures requiring an abdominal fat tissue or salivary gland biopsy. There are efforts to detect amyloid deposition noninvasively. Recently, noninvasive MR elastography has been investigated for its potential use in cardiac and hepatic amyloidosis. Additionally, positron emission tomography (PET) agents are in clinical practice for detection of amyloid both in Alzheimer disease and cardiac amyloidosis (14). However, PET causes radiation exposure, and MR imaging is technically and logistically difficult to organize in pediatric age group.

Sonoelastography has been widely investigated for its potential use in tissue fibrosis. Ultrasound elastography has been investigated for its potential diagnostic utility in differentiation of focal salivary gland lesions, parenchymal salivary gland disease like Sjogren's syndrome. Additionally, since children may have variable soft tissue elasticity by age, there have been studies investigating the normal elasticity values. In cases of chronic inflammation secondary to infectious (10) or chronic inflammatory (11) diseases, elastography showed increased tissue stiffness. However, there was no previous study investigating the role of elastography in FMF and amyloidosis. In this study, we showed an increased tissue elasticity in FMF patients with and without amyloidosis compared to the control subjects. This indicates that even though amyloidosis is not clinically overt, FMF causes increased stiffness of these glands. In our study, although there were higher elasticity values in FMF patients with amyloidosis compared to FMF patients without known amyloidosis, this difference failed to reach statictical significance. This result may be caused by subclinical amyloid deposition in patients without histopathological evaluation. We could not exclude tissue amyloidosis in colchicine resistant FMF patients without histopathological evaluation. Additionally, this might be related to the relatively limited number of patients in the amyloidosis group. In addition, we depicted that severe inflammation effects tissue stiffness based on the negative correlations of the acute phase reactants with tissue stiffness. However, recurrent inflammatory episodes contributed to an increased overall tissue stiffness. Therefore, tissue elasticity could be performed for patient follow-up. US-based elastographic evaluation, could be considered as the first choice method in the development of amyloidosis in pediatric patients.

Being aware of normative tissue elasticity in children would facilitate an evaluation of the SWE results in patient groups. In recent years, there have been a few studies conducted on elastographic evaluation of salivary glands in children.Strain index comparing parotid gland stiffness to surrounding subcutaneous soft tissue has been found to be $1.24 \pm 0.67$ (15), and strain index for normal thyroid parenchyma in comparison with surrounding subcutaneous soft tissue has been found to be $0.54 \pm 0.38$ (16) in children with strain elastography. Submandibular gland strain index has not been investigated compared to periglandular soft tissues in children. As comparable with our results, the mean elasticity values by SWE in children for the thyroid, submandibular, and parotid glands were reported to be $14.6 \pm 3.3 \mathrm{kPa}, 11.8 \pm 2.2 \mathrm{kPa}$, and $11.8 \pm 2.6$ $\mathrm{kPa}$, respectively (17). In a recent study for parotid gland SWE, mean elasticity was found to be $9 \mathrm{kPa}$ in a healthy pediatric population (18). In our study, the normal parotid gland elasticity value we depicted was similar to those of Çalışkan et al. but the median submandibular and thyroid gland elasticity values in healthy children were found to be lower than the previous study (17). These results may be caused due to different US devices although the method is similar as SWE. All of the FMF and amyloidosis patients presented homogeneous thyroid and salivaryglands contrary to the previous findings by Law et. al, however echogenicity of the salivary glands in cases with amyloidosis was increased. Changes in echogenicity have been expressed subjectively in routine ultrasound practise but tissue elastography is a measurable and objective data. We suggest evaluating the patients with the same ultrasonic device equipped with elastography during follow-up.

There are several limitations to our study. First, we saw a limited number of cases diagnosed with amyloidosis that were mildly older than the FMF group. This was because of the early diagnosis of FMF patients in the tertiary center, inclusion of initial periods of FMF in early childhood, 
and also being a progressive disease that may result in mortality. Also some of the patients with amyloidosis had been admitted to radiology department for other consultations and we could not use their labaratory results. Secondly, elasticity assessment and laboratory data were obtained in patients with acute admission within a week and we can not foresee the results of very early examinations in 24 hours. Third, because of the limited number of cases we could not investigate the association between the degree of amyloid deposition with tissue elasticity. Fourth, most of the cases were resistant to the colchicine and under medication with biologic agents. Mild cases under control with colchicine and FMF outpatients without an acute attack were not included. Future studies including these patients could be performed.

In conclusion, we showed an increased tissue elasticity in FMF patients with and without amyloidosis compared to control subjects. This indicates that even though amyloidosis is not clinically overt, FMF causes increased stiffness of salivary glands. Increased tissue stiffness during longitudinal follow-up would suggest the development or progression of amyloidosis. US-based elastographic evaluation could be considered as the first choice method in follow-up of pediatric patients with FMF.

Etik Komite Onayı: Bu çalışma için etik komite onayı İstanbul Üniversitesi Yerel Etik Kurulu'ndan alınmıştır. (No: 2017/1182)

Bilgilendirilmiş Onam: Katılımcılardan bilgilendirilmiş onam alınmıştır.

Hakem Değerlendirmesi: Dış bağımsız.

Yazar Katkıları: Çalışma Konsepti/Tasarım- Z.B., I.A., R.E.Ö.; Veri Toplama- Z.B., O.K.; Veri Analizi/Yorumlama- Z.B., O.K., S.G.K., i.A., R.E.Ö.; Yazı Taslağı- Z.B., O.K., S.G.K., i.A., R.E.Ö.; İçeriğin Eleştirel Inncelemesi- i.A., R.E.Ö.; Son Onay ve Sorumluluk- Z.B., O.K., S.G.K., I.A., R.E.; Malzeme ve Teknik Destek- I.A., R.E.Ö.; Süpervizyon- I.A., R.E.Ö.

Çıkar Çatışması: Yazarlar çıkar çatışması beyan etmemişlerdir.

Finansal Destek: Yazarlar finansal destek beyan etmemişlerdir.

Ethics Committee Approval: This study was approved by the Istanbul Medical Faculty Local Ethics Committee. (No: 2015/1738)

Informed Consent: Written consent was obtained from the participants.

Peer Review: Externally peer-reviewed.

Author Contributions: Conception/Design of Study- Z.B., I.A., R.E.Ö.; Data Acquisition- Z.B., O.K.; Data Analysis/Interpretation- Z.B., O.K., S.G.K., I.A., R.E.; Drafting Manuscript- Z.B., O.K., S.G.K., I.A., R.E.Ö.; Critical Revision of Manuscript- I.A., R.E.Ö.;
Final Approval and Accountability- Z.B., O.K., S.G.K., I.A., R.E.Ö.; Technical or Material Support- I.A., R.E.Ö.; Supervision- I.A., R.E.Ö.

Conflict of Interest: Authors declared no conflict of interest.

Financial Disclosure: Authors declared no financial support.

\section{REFERENCES}

1. Sari I, Birlik M, Kasifoglu T. Familial Mediterranean fever: An updated review. Eur J Rheumatol 2014;1(1):21-33. [CrossRef]

2. Alghamdi M. Familial Mediterranean fever, review of the literature. Clin Rheumatol 2017;36(8):1707-13. [CrossRef]

3. Bakan S, Kandemirli SG, Akbas S, Cingoz M, Ozcan Guzelbey B, Kantarci F, et al. Amyloid Goiter: A Diagnosis to Consider in Diffuse Fatty Infiltration of the Thyroid. J Ultrasound Med 2017;36(5):1045-9. [CrossRef]

4. Trifanov DS, Dhyani M, Bledsoe JR, Misdraji J, Bhan AK, Chung RT, et al. Amyloidosis of the liver on shear wave elastography: case report and review of literature. Abdom Imaging 2015;40(8):3078-83. [CrossRef]

5. Yalcinkaya F, Cakar N, Acar B, Tutar E, Guriz H, Elhan AH, et al. The value of the levels of acute phase reactants for the prediction of familial Mediterranean fever associated amyloidosis: a case control study. Rheumatol Int 2007;27(6):517-22. [CrossRef]

6. Law ST, Jafarzadeh SR, Govender P, Sun X, Sanchorawala $V$, Kissin EY. Comparison of Ultrasound Features of Major Salivary Glands in Sarcoidosis, Amyloidosis, and Sjogren's Syndrome. Arthritis Care Res 2019;15. [CrossRef]

7. Gianstefani A, Salvatore V, Crespi C, Bolondi L. Stiffness and amyloidosis: to be continued. Eur J Gastroen Hepat 2010;22(12):1507. [CrossRef]

8. Janssens F, Spahr L, Rubbia-Brandt L, Giostra E, Bihl F. Hepatic amyloidosis increases liver stiffness measured by transient elastography. Acta Gastro-Ent Belg 2010;73(1):52-4.

9. Lanzi A, Gianstefani A, Mirarchi MG, Pini P, Conti F, Bolondi L. Liver AL amyloidosis as a possible cause of high liver stiffness values. Eur J Gastroen Hepat 2010;22(7):895-7. [CrossRef]

10. Kara M, Caliskan E, Atay G, Sutcu M, Kaba O, Adaletli I, et al. Shear wave elastography of parotid glands in pediatric patients with HIV infection. Radiol Med 2019;124(2):126-31. [CrossRef]

11. Turnaoglu H, Kural Rahatli F, Pamukcu M, Haberal KM, Uslu N. Diagnostic value of acustic radiation force impulse imaging in the assessment of salivary gland involvement in primary Sjogren's sydrome. MedUltrason 2018;20(3):313-8. [CrossRef]

12. Zengel P, Reichel CA, Vincek T, Clevert DA. Ultrasound elastography in diagnosis and follow-up for patients with chronic recurrent parotitis. Clin Hemorheol Microcirc 2017;67(3-4):389-97. [CrossRef]

13. Tunca M, Akar S, Onen F, Ozdogan H, Kasapcopur O, Yalcinkaya F, et al. Turkish FMF Study Group. Familial Mediterranean fever (FMF) in Turkey: results of a nationwide multicenter study. Medicine (Baltimore) 2005;84(1):1-11. [CrossRef]

14. Law WP, Wang WY, Moore PT, Mollee PN, Ng AC. Cardiac Amyloid Imaging with 18F-Florbetaben PET: A Pilot Study. J Nucl Med 2016;57(11):1733-9. [CrossRef] 
15. Gungor G, Yurttutan N, Bilal N, Menzilcioglu MS, Duymus M, Avcu S, et al. Evaluation of Parotid Glands With Real-time Ultrasound Elastography in Children. J Ultrasound Med 2016;35(3):611-5. [CrossRef]

16. Yurttutan N, Gungor G, Bilal N, Kizildag B, Baykara M, Sarica MA. Interpretation of thyroid glands in a group of healthy children: real-time ultrasonography elastography study. J Pediatr Endocrinol Metab 2016;29(8):933-7. [CrossRef]
17. Arioz Habibi H, Memis Durmaz ES, Qarayeva V, Kandemirli SG, Kalyoncu Ucar A, Aslan M, et al. Quantitative Assessment of Thyroid, Submandibular, and Parotid Glands Elasticity With Shear-Wave Elastography in Children. Ultrasound Q 2018;34(2):58-61. [CrossRef]

18. Caliskan E, Ozturk M, Bayramoglu Z, Comert RG, Adaletli I. Evaluation of parotid glands in healthy children and adolescents using shear wave elastography and superb microvascular imaging. Radiol Med 2018;123(9):710-8. [CrossRef] 